\title{
A Typology of Ancient Purépecha (Tarascan) Architecture from Angamuco, Michoacán, Mexico
}

\author{
Christopher T. Fisher, Anna S. Cohen, Rodrigo Solinis-Casparius, Florencia L. Pezzutti, Jason Bush, \\ Marion Forest, and Andrea Torvinen
}

\begin{abstract}
The morphological study of architectural features, the building arrangement within urban spaces, and multiscalar variation are critical for understanding urbanism as a process. Building types and architectural typologies form the foundational blocks of urban morphology and are essential for identifying architectural patterning. We use a process-typological approach to present an architectural typology from the ancient Purépecha (Tarascan) city of Angamuco, located in the Lake Pátzcuaro Basin, Michoacán, Mexico. Using archaeological survey, lidar analysis, and excavation, we analyze building foundations from houses and public structures; storage facilities; monumental architecture such as pyramids, altars, and public buildings; and landscape features such as plazas, roads, terraces, and raised roadways locally known as huatziri. Our typology enhances understanding of the dense urban environment of this important prehispanic city during and after the formation of the Purépecha Empire.
\end{abstract}

Keywords: architecture, typology, urbanism, Mesoamerica

El estudio morfológico de los rasgos arquitectónicos, de la configuración de construcciones dentro de espacios urbanos y de la variación multiescalar es fundamental para entender el urbanismo como proceso. Los tipos de edificios y las tipologías arquitectónicas forman los bloques fundamentales de la morfología urbana y son esenciales para identificar patrones arquitectónicos. Aquí usamos un enfoque procesual-tipológico para presentar una tipología arquitectónica de la antigua ciudad Purépecha (Tarasca) de Angamuco, ubicada en la cuenca del Lago de Pátzcuaro, Michoacán, México, basada en prospecciones arqueológicas, análisis de datos lidar y excavaciones. Este trabajo incluye cimientos de edificaciones habitacionales y estructuras públicas, construcciones para almacenamiento, estructuras monumentales tales como pirámides, altares y edificios públicos y elementos del entorno construido tales como plazas, caminos, terrazas y calzadas elevadas conocidos localmente como huatziri. Nuestra tipología nos permite comenzar a comprender el denso entorno urbano de esta importante ciudad prehispánica durante y después de la formación del imperio Purépecha.

Palabras Clave: arquitectura, tipología, urbanismo, Mesoamérica

Christopher T. Fisher $\square$ Department of Anthropology, Colorado State University, B-219 Andrew G. Clark Building, Fort Collins, CO 80523, USA (Ctfisher@ colostate.edu, corresponding author)

Anna S. Cohen $\square$ Department of Anthropology, Utah State University, Old Main 0730, Logan, UT 84322, USA

(anna.cohen@usu.edu)

Rodrigo Solinis-Casparius - Department of Anthropology, University of Washington, 314 Denny Hall, Seattle, WA 98195, USA (rsolinis@uw.edu)

Florencia L. Pezzutti — Department of Anthropology, Colorado State University, B-219 Andrew G. Clark Building, Fort Collins, CO 80523, USA (Florencia.Pezzutti@ colostate.edu)

Jason Bush — Defense POW/MIA Accounting Agency, 590 Moffet St., Joint Base Pearl Harbor-Hickam, HI 96853, USA (bushdoctor75@gmail.com)

Marion Forest — Department of Anthropology, Brigham Young University, 800 SWKT, Provo, UT 84604, USA (marion_forest@ byu.edu)

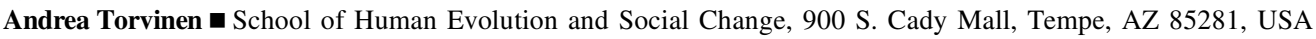
(atorvine@asu.edu)

Latin American Antiquity 30(3), 2019, pp. 510-528

Copyright $(2019$ by the Society for American Archaeology. This is an Open Access article, distributed under the terms of the Creative Commons Attribution licence (http://creativecommons.org/licenses/by/4.0/), which permits unrestricted re-use, distribution, and reproduction in any medium, provided the original work is properly cited.

doi:10.1017/laq.2019.50 


\section{Architecture and Urbanism}

$\mathrm{A}$ ncient cities are the result of long trajectories of socioecological evolution that can yield insights relevant to modern urban planners, policy makers, and stakeholders (Batty 2008; Carballo and Fortenberry 2015; Marcus and Sabloff 2008; Ortman et al. 2014; M. E. Smith 2007, 2011; M. L. Smith 2003, 2014; Stanley et al. 2016; York et al. 2011). The morphological study of architectural features and building arrangement within urban spaces is critical for understanding urbanism as a process (M. L. Smith 2003; Steadman 2016). Building types and architectural typologies form the foundational blocks of urban morphology and are essential for identifying architectural patterning (Oliveira 2016).

Using a process-typological approach (Oliveira et al. 2015), we present an architectural typology from the ancient Purépecha (Tarascan) city of Angamuco, located in the Lake Pátzcuaro Basin, Michoacán, Mexico (Figure 1). Angamuco contains more than 40,000 stone and earthen architectural features (Fisher et al. 2017; see Figure 2). The site was occupied before and during the development of the Late Postclassic Purépecha Empire (AD 1350-1530; all dates in this article are $\mathrm{AD}$ ), which makes it a useful context for evaluating changing urban spatial organization during a period of dramatic sociopolitical fluctuation.

Since 2009, we have used an architectural typology for Angamuco, which is based on a fieldverified, intensively mapped sample of more than 7,000 architectural features (roughly 17\% of the estimated total number of buildings at the site). These features include building foundations from houses and public structures; storage facilities; monumental architecture such as pyramids, altars, and public buildings; and landscape features such as plazas, roads, terraces, and raised roadways (huatziri). In this article, we discuss the Angamuco typology and how it has helped us gain insights into the development of social complexity and urbanism throughout the course of the Purépecha Empire.

Architecture is the intentional human manipulation of the environment derived from cultural norms, historical contingency, and social memory.
The construction of architecture focuses human activities along both functional and sociopolitical realms. Our definition follows a structured approach in which architecture is a material expression of culture that can yield fundamental insights into sociopolitical organization (Bourdieu 1977; Giddens 1984). This inclusive definition refers to both buildings and those environmental features that distinguish between mere physical spaces and "places" and those where we engage in social processes (Alejandro Villafanez 2011; Anschuetz et al. 2001; Ashmore 2002, 2015; Bradley 2000; Ingold 1993; Joyce and Goman 2012; Lippard 1997; Walker 2012). In this sense, architecture is imbued with social meaning and experiences. For example, it manages the way that the landscape is experienced by creating viewsheds (geographical areas visible from a given location) and by controlling access to certain places based on hierarchy, class, and status (Barrett 1994; Johnson 2012; Tilley 1994).

Buildings and landscape features such as terraces form the urban "tissue" of ancient cities: the arrangement of blocks and streets or the demarcation of space (Scheer 2010:47-48). Architecture is the underlying determinant of the urban tissue, meaning that urban morphology cannot be discerned without a basic knowledge of building forms over time. Thus, an architectural typology - which classifies and defines human-modified features within a landscapeplays a fundamental role in understanding factors involved in the rise, fall, and growth of ancient urban centers.

\section{Angamuco and the Lake Pátzcuaro Basin}

In 1519, central and central-western Mexico was dominated by two empires: the Aztecs in the Basin of Mexico and the Purépecha (Tarascans) within the Lake Pátzcuaro Basin (LPB). The LPB contained the capital city of Tzintzuntzan that was the core of a centralized tribute system; it was characterized by a socially stratified population and an engineered environment with widespread terracing and landscape modification (Fisher et al. 2013; Pollard 1993, 2003).

In 2007, the Legacies of Resilience: The Lake Pátzcuaro Archaeological Project (LORE-LPB) 


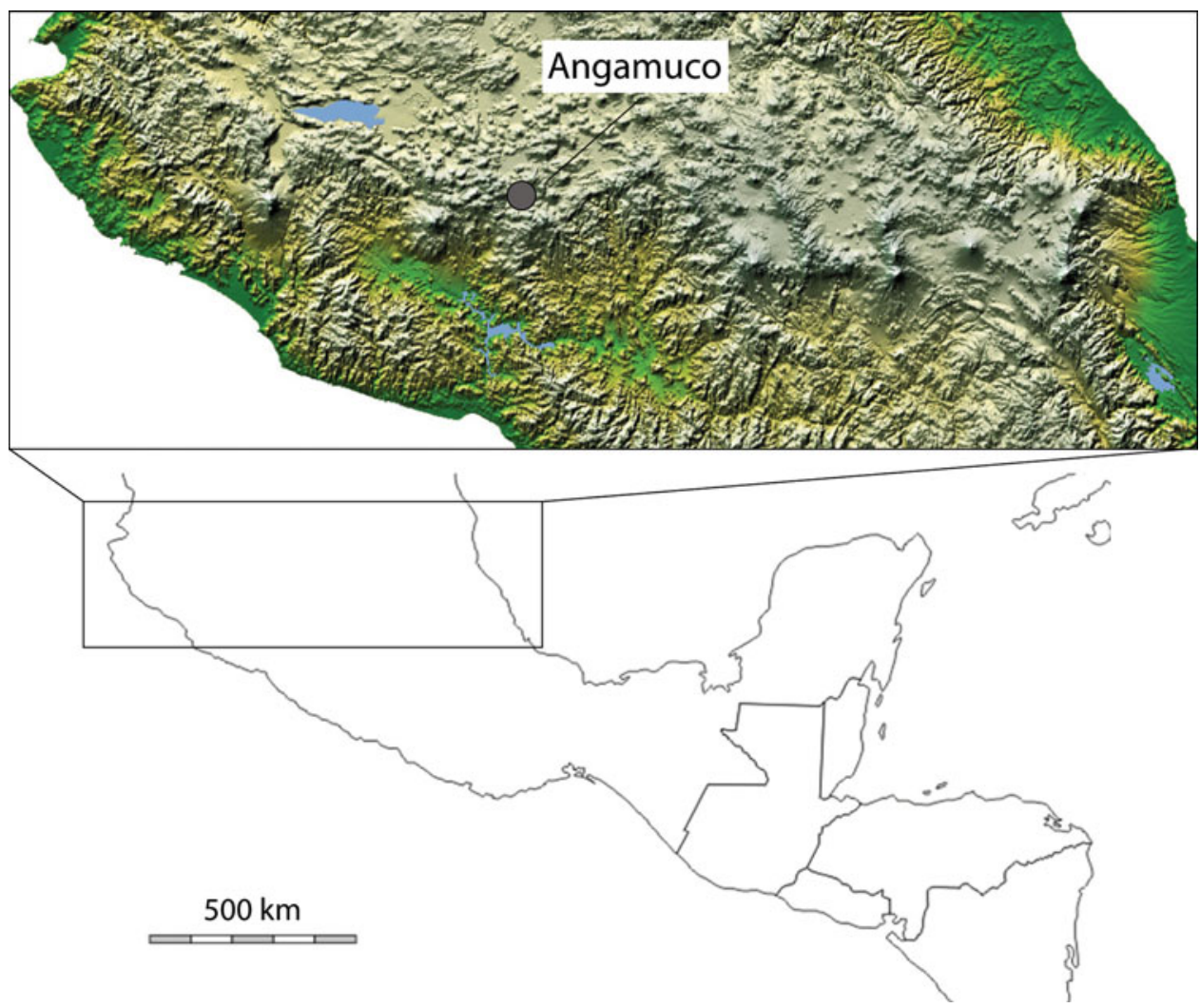

Figure 1. Location of the Lake Pátzcuaro Basin within Mesoamerica. Image from shuttle radar data.

identified a settlement $5 \mathrm{~km}$ east of Tzintzuntzan that was large and undocumented. We named this site Angamuco (Sacapu Angamuco), based on a colonial settlement located in that general region (Beaumont 1932; Roskamp 1997). Angamuco occupies a late Pleistocene lava flow ( $\mathrm{mal}$ país) on the eastern boundary of the LPB. Because this landform is not suitable for modern agriculture, thousands of building foundations are well preserved: they include platforms, pyramids, roads, terraces, granaries, and walls manufactured from stacked stone with undisturbed floors, middens, and other deposits.

From 2009 to 2012, LORE-LPB conducted urban mapping to better understand the age, size, number, variation in form, and spatial organization of structures present at Angamuco (Fisher, Bush et al. 2011; Fisher et al. 2012). We supplemented this work with lidar scanning covering an area of just over $35 \mathrm{~km}^{2}$ of Angamuco and adjacent areas (Fisher and Leisz 2013; Fisher, Leisz, and Outlaw 2011; Fisher et al. 2017). Following the lidar survey in 2013-2014, we excavated seven locations of the site to better field-verify and understand the lidar data and to provide temporal control (Fisher et al. 2013, 2016).

Analysis of the complete lidar dataset shows that the entire malpaís landform of $26 \mathrm{~km}^{2}$ is covered with architectural features of varying densities (Fisher et al. 2017). The most intensively occupied portions are distinct monumental zones distributed throughout the malpaís. This multinucleated settlement is unusual for Mesoamerica (Mastache et al. 2008; Sanders et al. 2003) and potentially for the Purépecha Empire (Pollard 2003). This also means that Angamuco is an example of an urban landscape similar to what has been observed at Cantona and the Malpaís of Zacapu (e.g., Cook and Carrión 1998; Forest 2017; Millon 1973). We have documented more than 60 distinctive, standardized, and recurrent architectural forms throughout the site, including commoner and elite buildings, altars, 


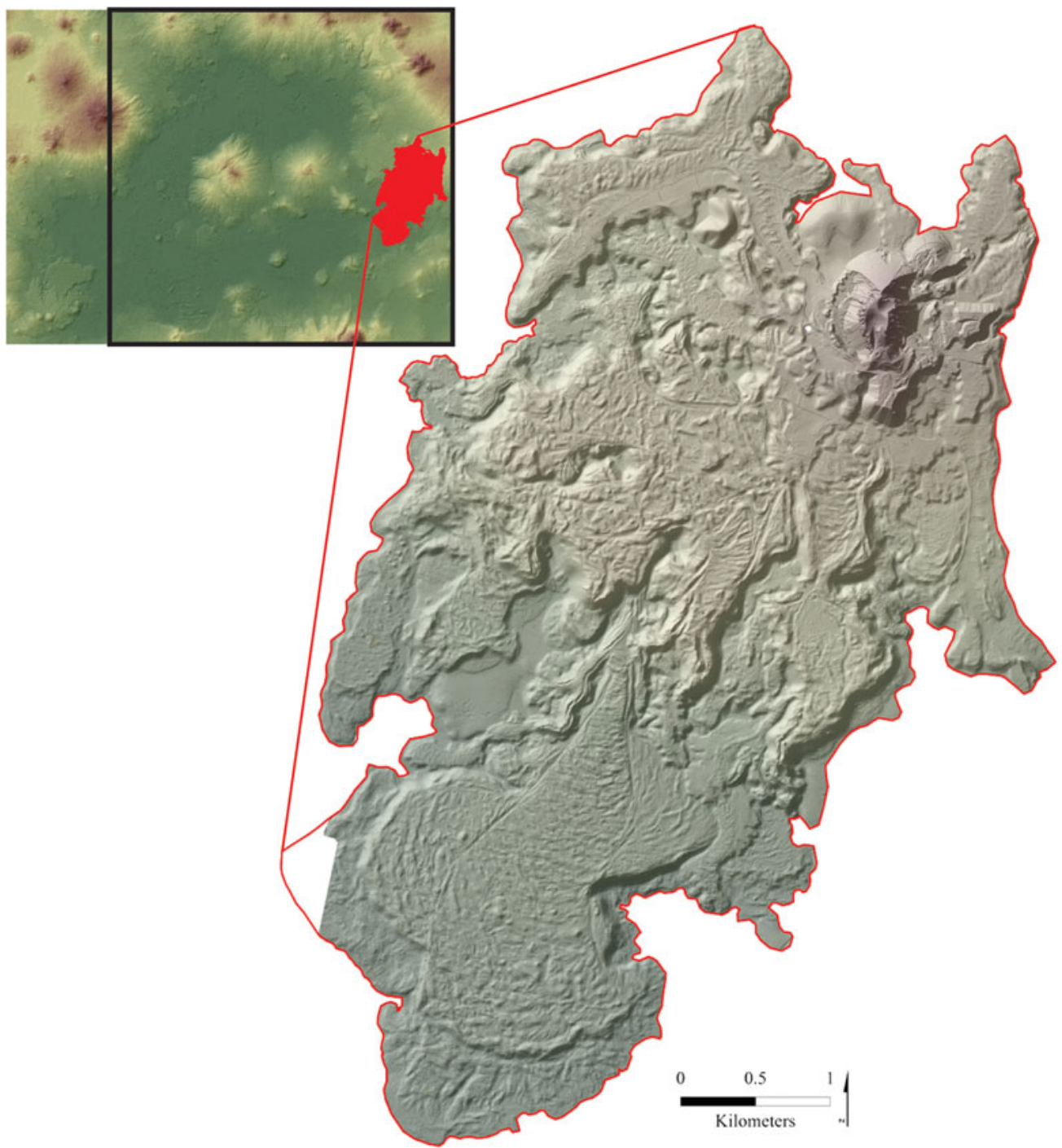

Figure 2. The city of Angamuco within the LPB.

pyramids, storage facilities, ball courts, and a hierarchical road system. Based on survey data and sampled counting of unsurveyed zones, we estimate that more than 40,000 architectural foundations are present within our suggested boundaries of Angamuco.

Survey, lidar analysis, and excavation demonstrate that Angamuco was occupied from at least the Classic to Contact periods (300-1530), with a primary occupation during the Early to Middle Postclassic periods (900-1350; Cohen 2016). During the Epiclassic and Early Postclassic periods (600-1200), architecture consisted of sunken patio complexes similar to those from the Bajío region of Mexico (Cárdenas-García 1999; Darras and Faugère 2005; Faugère-Kalfon 1996). Construction expanded during the Middle Postclassic (1200-1350), when the settlement was centered around several nodes with distinct rectilinear pyramid complexes similar to those documented for the nearby Zacapu Basin (Arnauld and Faugère-Kalfon 1998; Forest 2014; Michelet 2008). During the Late Postclassic period, the settlement contracted and focused around at least two nodes with Purépecha imperial-style architecture. The shape of features (circular and 
square) showed increased variety in architectural form that could relate to the diversification of activities, and their accessibility and location suggested social differentiation. Our preliminary results indicate that, for much of the Postclassic period, Angamuco dominated the eastern portion of the LPB with its large population and territory, extensive built environment, and several civicceremonial nodes.

\section{Architecure at Angamuco}

An initial version of the architectural typology described here was created in 2007 for a fullcoverage survey on the former island of Apúpato (Pezzutti 2010). It included a data dictionary with drop-down menus that was then entered into a relational database. The typology was updated and expanded in 2009 for the initial season of mapping/survey at Angamuco and was incrementally modified in subsequent years to reflect the types of features encountered at the site (for early versions, see Ahrens 2013; Bush 2012; Cohen 2016; Fisher, Bush et al. 2011; Urquhart 2015). The 2010 version was printed, laminated, and carried in the field by trained archaeologists as a quick reference.

Thousands of ancient buildings and associated landscape features are visible on the surface of Angamuco. The natural surface of the malpaís is irregular and punctuated by ridges, swales, and faults. All of the architecture at Angamuco is composed of stacked, uncut stone that lacks preserved mortar. Foundations are constructed from basalt boulders and slabs removed from the surface or mined from shallow depths within the site. Walls, interior features, and other monumental structures would have been covered with adobe/plaster. It is also likely that some stone structures supported a superstructure of walls made from adobe, wood, or other perishable materials. Mounds, pyramids, and platforms are rubble filled and faced with stacked stone.

Inherent in any typology is the tendency to classify examples that do not conform to existing types; therefore, typologies must leave room for nonconformity. Given the long period of occupation, postdepositional disturbance, and the presence of open-sided structures and walls built from perishable materials, this is especially important for Angamuco. Consequently, we used the concept of the "minimal architectural unit (MAU)," meaning that all architecture at Angamuco that did not conform to a type was classified by the largest component possible. Doing so enabled researchers to document features that did not directly conform to the bestdefined types outlined in this section. The complete typology is shown illustrated as flowcharts in Supplemental Figure 1.

\section{Buildings and Landscape Features}

In our analysis, we divide the Angamuco architecture into two basic groups: buildings and landscape features. Buildings are embedded in the urban tissue of a city and consist of walls that are often roofed. They are associated with mounds, platforms, or other similar features; serve as the foci for many human activities; and delimit spaces at specific points on the landscape. Buildings can accommodate a limited number of people and a restricted number of activities. In contrast, landscape features are informed by natural features such as topography and water, but they also connect the urban environment. Landscape features tend to delimit larger spaces according to access, ethnicity, class, and function; they include constructions such as plazas, roads, passages, and agricultural areas. Landscape features are both inclusive (e.g., plazas) and exclusive (e.g. private passages) and thus create both open and closed spaces.

\section{Types}

Typological systems constitute a fundamental element of classification and analysis that enables the understanding of social variation through time (Adams 1988; Dunnell 1986; Spaulding 1953). Architectural types form the basic spatial grammar of ancient urbanism and constitute the building blocks of the Angamuco typology. Following Scheer (2010), we define a type as a class of buildings that follow similar rules of morphology, function, placement within a settlement, and relationships to other buildings. Types are built on abstract conceptions of place and vary around a cultural norm (Johnson 2012; Preucel 2008; Steadman 2016). In this sense, architectural types codify cultural values 
and embed meaning, and they are not bound simply by function. For example, buildings and spaces enable activities related to the goals of multiple social actors, such as economic activities within domestic spaces (Allison 2013; Carballo 2011).

\section{The Angamuco Typology}

Our typology is best illustrated as a series of flowcharts (Supplemental Figure 1). Following the MAU principle, a researcher can move through each flowchart using partial or fragmentary features, such as a single wall. The Angamuco typology begins by defining broad categories based on whether a feature is above or below ground (e.g., Ashmore 1981). An above-ground feature, for example, would typically be located on a building or other feature placed on a platform or mound. In contrast, a ground-level feature, such as a wall, possesses a foundation at ground surface.

\section{Ground-Level Features}

Platforms. Platforms are above-ground structures with one level (cuerpo) and a plan that is wider than a single course of stones (Supplemental Figure 1A). Platform cuerpos average around $50 \mathrm{~cm}$ in height, although some are taller. The plan for platforms is highly varied, ranging from abstract through compound shapes for buildings to more linear forms for landscape features. Most platforms are generally freestanding and can form the walls of buildings and serve as a base for a structure. In some instances, platforms may be connected to one another to form compound structures. Based on their shape, size, association, and context, we identified four platform types.

The first platform type is characterized as having a square or rectilinear plan. Simple square platforms are composed of a single square feature, whereas double square platforms consist of two features with a division. In double examples, one of the platforms is significantly smaller in size, and the division is often a passage feature resembling a dripline. The function of the second platform remains unknown, although it may be a kitchen or other outbuilding. In contrast, simple square platforms often served as a superstructure for above-ground buildings that ranged from storage or domestic structures to larger public buildings. In many instances, the foundations for Type B and C buildings (see the later discussion) are visible on the top of the platform, along with hearth or oven features (fogónes) and stairs leading to the entrance of the building. Additionally, postholes can be seen on the sides of some platforms. It is possible that some platforms supported freestanding wooden structures like modern trojes, a form of colonial building with a shake roof (Barthelemy and Meyer 1987; Beals and Carrasco 1944:33-36; Beals et al. 1944; Lumholtz 1987:365; West 1948:27-32).

The second platform type is circular and is defined by a lack of corners and sides that are equidistant from a central point. Although the sample of these features is small, we believe that they served as a foundation for both storage features (cuexcomates) and larger circular buildings as illustrated in the Relación de Michoacán (RM; see Ahrens 2013; Alcalá 2000). The function of the larger circular buildings remains unknown.

The final two platform types were likely functionally similar to walls (see the later discussion) but are wider than a single or double course of stones with a rubble core. L-shaped platforms have a 90 -degree angle, forming a square building with two open sides. One side is longer than the other, and sometimes the shorter side is a square mound with a perishable structure on top. Though none of these features have been excavated, they may represent a small enclosed building (Type B or C). Based on depictions in the RM and excavations at Lagunillas in Michoacán, these features may represent a small enclosed building attached to a porch on which an elite received subjects (e.g., Alcalá 2000; Robles et al. 2014). Linear platforms are rectangular and may have served the same function as simple walls - demarking roads, groups of buildings, and other landscape features. Others likely delimited larger spaces for defense or for restricting access.

Huatziri. A distinctive type of platform, called huatziri in Purépecha (muro-calzada or road wall), is visible on the outer boundary of complejos and other boundary features at Angamuco (Figure 3). Huatziri are characterized by a 
single, tall $(\sim 2.5 \mathrm{~m})$ level of rubble faced with large stacked stone, a width of $1 \mathrm{~m}$, and a flat top (compacted or paved). They have been documented in other Purépecha cities like Ihuatzio (12 km west of Angamuco) where they were probably used as processional walkways for ceremonial activities (Cárdenas García 1991, 1992, 1993, 2004; Du Solier 1936; Marquina 1929; Michelet 2008; Rubín de la Borbolla 1939).

In addition to the basic huatziri type, there are at least two variations in terms of construction, size, and shape. The most common at the site is a much smaller $(<1 \mathrm{~m}$ height $)$ version that can easily be described as a raised road or causeway (calzada; Bolles and Folan 2001; Chase and Chase 2001; Denevan 1990). Another distinct type contains a second smaller step attached to the main section (Figure 3d). This additional course is smaller and lower in height than the primary cuerpo, is visible on one side only, and runs the full length of the main feature. Some of these examples are located on slopes, so they were likely designed as landscape elements.

Huatziris are not always continuous but sometimes have gaps and open sections along with adjacent portions that lack a connection. Although some of these openings are clearly entrances into compartmentalized sections of the city that lead directly into roads, others are more puzzling. A massive stone wall runs north-south at the Aztec city of Huexotla, and although fragmented, it may be similar to the wall surrounding the Sacred Precinct at Tenochtitlan (M. E. Smith 2008:39-41). The intentional breaks underscore the multifunctionality of these features.

Mounds. Mounds are distinguished from platforms by the presence of more than one cuerpo and can be divided into pyramids or altars. Pyramids occur throughout the site and anchor civic-ceremonial nodes or neighborhoods (Fisher and Leisz 2013). Different types of pyramids also occur in association within the same neighborhood, reinforcing the notion that these prototypes have unique functional attributes.

Yácata Pyramids. The most distinctive pyramid at Angamuco is a composite shape formed by a conjoined circular and rectilinear element connected at the center by a short linear platform. The result is a stepped pyramid with a keyhole- shaped plan created by combining a circular, linear, and rectilinear mound. The primary axis runs along the central connecting portion, with a secondary axis that follows the long direction of the rectilinear section. Access to the top of the structure is varied and occurs by stairs that cover the stepped portion either on the open face or on the sides of the rectilinear portion. Stairs from the ground surface do not seem to be associated with the circular section. Once on top, access to the circular section is possible either directly from the rectilinear element or along a short connecting platform that runs between the circular and rectilinear elements.

In western Mexico, the semicircular yácata form served as a marker of Purépecha authority (e.g., Acosta 1939; Gali 1946; Goggin 1943; León 1886; Lumholtz 1987; Pepper 1916; Rubín de la Borbolla 1941, 1944; West 1948). At Angamuco, there are at least five clear yácata examples that vary by size, orientation, and morphology. The largest yácata yet documented at Angamuco (MO 5037; Figure 4) was associated with adjacent excavations in 2014 (Cohen 2016:193-215). The circular section has dimensions of $17.5 \times 19 \mathrm{~m}$, whereas the rectilinear section is $34 \times 13 \mathrm{~m}$. Courses on both sections includes several steps that are $1 \mathrm{~m}$ wide and $80 \mathrm{~cm}$ tall and that were likely stairways to the top of the pyramid. The overall height of the structure is approximately $6 \mathrm{~m}$ tall, although some modern looting has affected this dimension. On the top of the circular portion, we documented the remains of a large room $(4 \times 6 \mathrm{~m})$ with stone floor remnants. Based on images in the RM, it is possible that a perishable structure with a thatched roof was also located on top of the rectangular portion. Access to the plaza features to the east and northeast of this yácata appear highly restricted, with specific points of entry. Consistent with the material from the adjacent excavation, this pyramid was used during the Middle to Late Postclassic periods (12001530 ), and it has a similar morphology to Purépecha examples at Tzintzuntzan, Ihuatzio, Pátzcuaro, Lagunillas, and San Juan Paragaricutiro (Acosta 1939; Castro-Leal Espino 1986; Lumholtz 1987; Robles et al. 2014; Rubín de la Borbolla 1941).

A potential earlier variant of the traditional yácata form is also present at Angamuco 

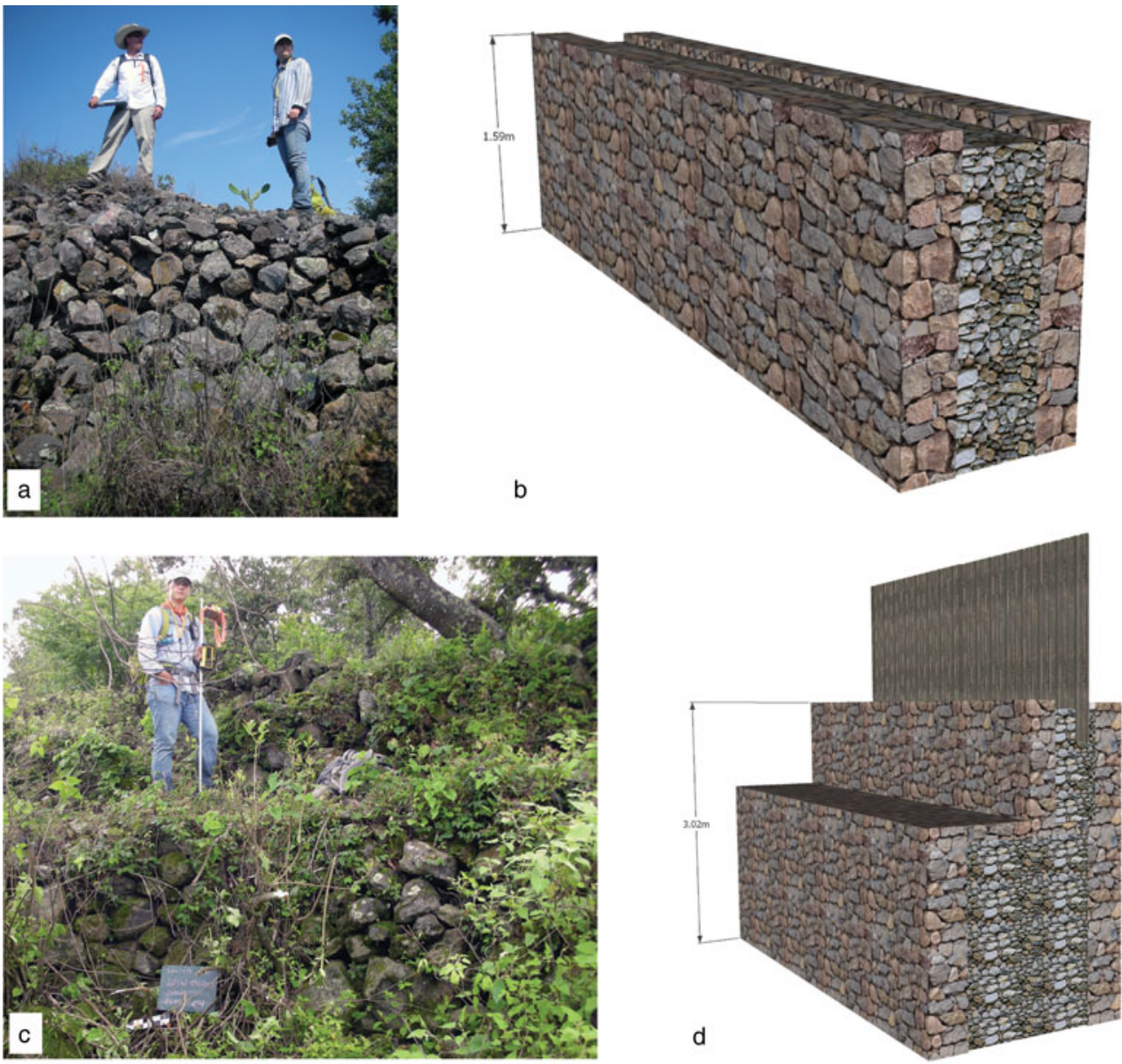

Figure 3. (a) Jason Bush and Andrea Torvinen on top of a huatziri. (b) Reconstruction of the feature based on intensive mapping. (c) Andrea Torvinen standing on the lower course of a huatziri with a bastion or step. (d) Reconstruction of this feature showing how a fence could have been built on the top as mentioned in the RM.

(building MO 2784; Supplemental Figure 3). In this example, the circular and the smaller rectilinear portions are directly joined together. Although postdepositional processes like looting damaged this yácata, four small steps are visible that have similar dimensions to yácata MO 5037 (described earlier). Access to the top of this feature likely came from the open side of the rectilinear portion, although this is unclear. The overall plan of this yácata is similar to Aztec pyramids dedicated to Ehecatl, an avatar of the feathered serpent Quetzalcoatl (Castro-Leal Espino1986; Pollock 1936; M. E. Smith 2008). Elsewhere, circular-based temples or pyramids have been documented at Classic period Teuchitlán sites (the guachimontes structures) in Jalisco and at Preclassic period Cuicuilco in southern Mexico City (discussion in Castro-Leal Espino 1986).

One more potential early yácata variation forms the edge of a sunken patio, with the rectilinear Pyramid 2768 anchoring one end (discussed later). The primary axis runs along the central connecting portion, and a secondary axis follows the long direction of the rectilinear section. This results in three façades for the rectilinear portion and a circular façade at the other end of the primary axis, which would have comprised the main visible portions of the structure, except for the perishable features on the top. The primary functional area of this structure was probably the top of the circular portion, access to which was 

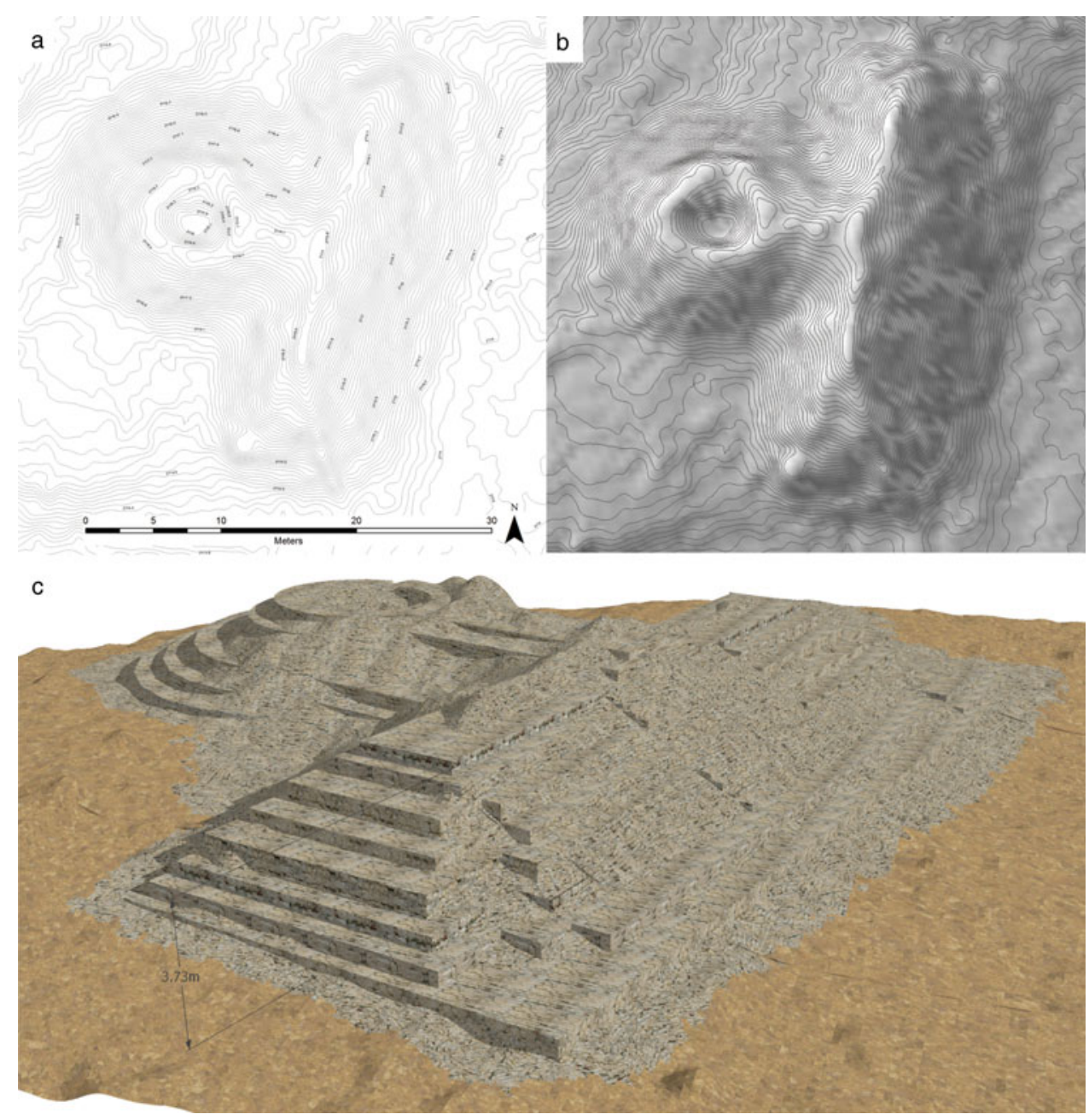

Figure 4: Yácata pyramid. (a) Plan view of this feature with a $5 \mathrm{~cm}$ contour map. (b) Perspective view of this feature using the contour map and a hillshade. Both are derived from $25 \mathrm{~cm}$ resolution lidar data. (c) Reconstruction based on intensive mapping.

restricted by a narrow stairway on the rectilinear portion that faced the adjacent sunken plaza.

Rectilinear Pyramids. The most common pyramids at Angamuco are rectilinear forms in which the primary axis is significantly shorter than the secondary axis. Access to this area comes from a stairway that runs along the primary axis that goes over the basal platform.

We have documented more than 20 rectilinear pyramids at Angamuco, and like the yácata form, they occur in a range of sizes and configurations. Some of these examples are associated with sunken plazas with the pyramid anchoring one end, which is similar to Epiclassic (600-900) examples from the Bajío (Cárdenas García 1999; Pomédio et al. 2013). The pyramid in Figure 5 is the largest rectilinear pyramid documented at Angamuco: it forms the northeast end of a plaza complex flanked by buildings to the west, south, and east sides, including a proto-yácata to the west. This example has at least four courses and is approximately $15 \mathrm{~m}$ high. The remains of a perishable structure, probably room type B (see the later discussion), occupy a small platform on the uppermost level. Access to the top of the pyramid would have been from a stairway along the primary axis on the west face, suggesting that the entrance faced the sunken plaza. Like 


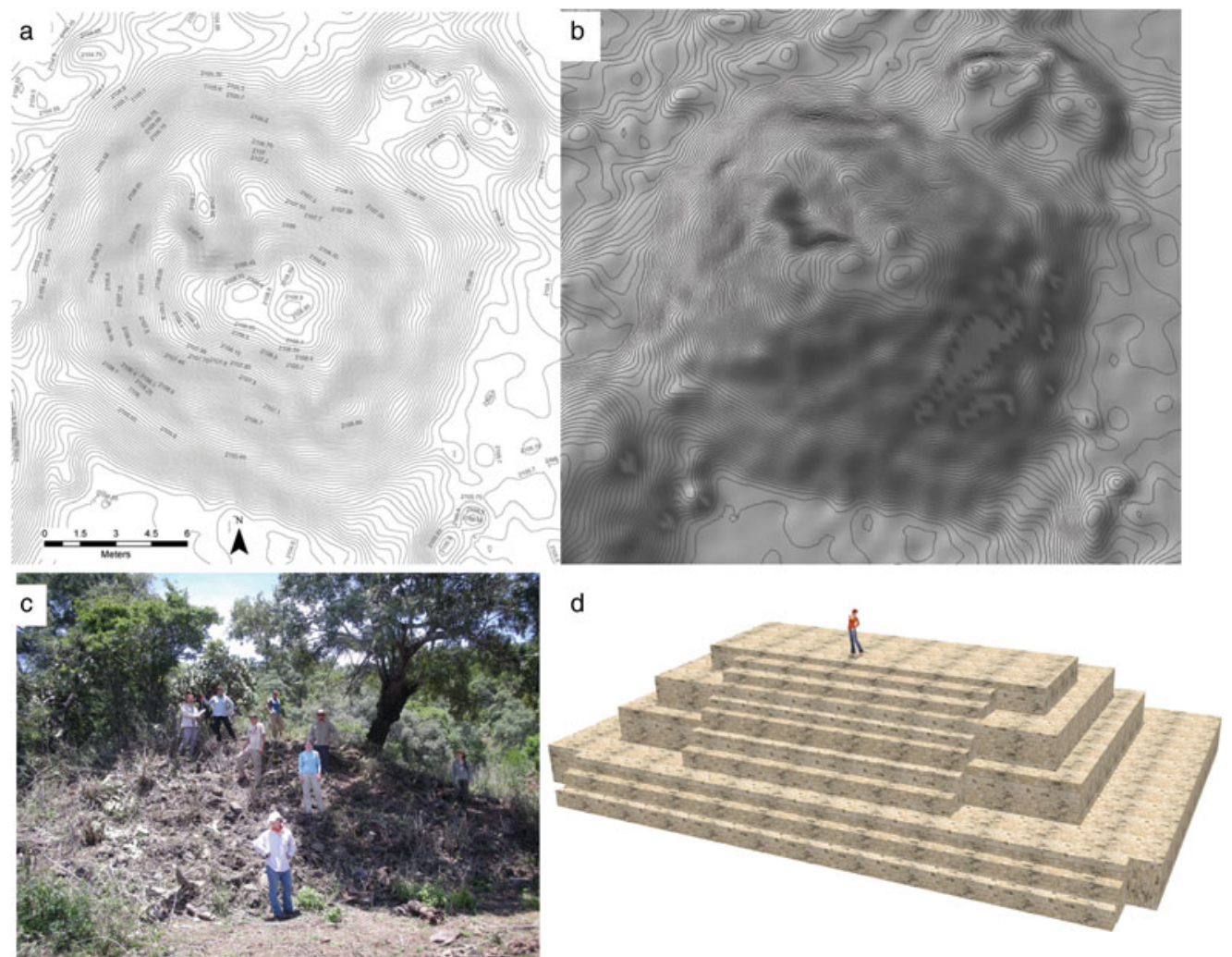

Figure 5. An example of a rectilinear pyramid (central depression is from looting). (a) Plan view of this feature with a $5 \mathrm{~cm}$ contour map. (b) Perspective view of this feature using the contour map and a hillshade. Both are derived from lidar data with a $25 \mathrm{~cm}$ resolution. (c) Photo of this feature after clearing. (d) Reconstruction based on intensive mapping.

the Middle Postclassic rectilinear pyramid contexts at the Malpaís of Zacapu and Las Milpillas, this Angamuco example likely served a ritual function associated with religious and funerary activities (Forest 2014; Pereira et al. 2012; Puaux 1989).

When Acosta and Rubin de la Borbolla excavated Ihuatzio in the 1930s, they documented both rectilinear-based and semicircular yácata pyramids and concluded that the former form relates to an earlier occupation (900-1200), whereas the latter relates to a later Purépecha occupation (1350-1530; Acosta 1939; Pollard 1993; Rubín de la Borbolla 1941). Although this work occurred before radiometric dating, their interpretation does support the idea that the rectilinear-based pyramids at Angamuco are like the earlier sunken plaza complexes in the Bajío and Tingambato and that the two forms represent different temporal periods.
Altars. The most common type of mound is the altar, a small stepped rectilinear feature found in the centers of plazas and patios, at the entrances or exits of road systems, and in some instances clustered together in groups. Like pyramids, they are composed of more than three cuerpos, but altars are distinguished by their smaller size and the presence of stairways at all sides. There is significant variation in the morphology and placement of these features, and with further research we may be able to identify multiple subtypes of these features.

The altar shown in Figure 6 is a rectilinear stepped mound with four courses and stairways on the west, south, and east sides. We excavated several units around this altar (MO 5001), which is one of two located in an open plaza flanked by yácata MO 5037 discussed earlier. This architectural configuration is similar to that found at Ihuatzio (Acosta 1939), and our excavations 


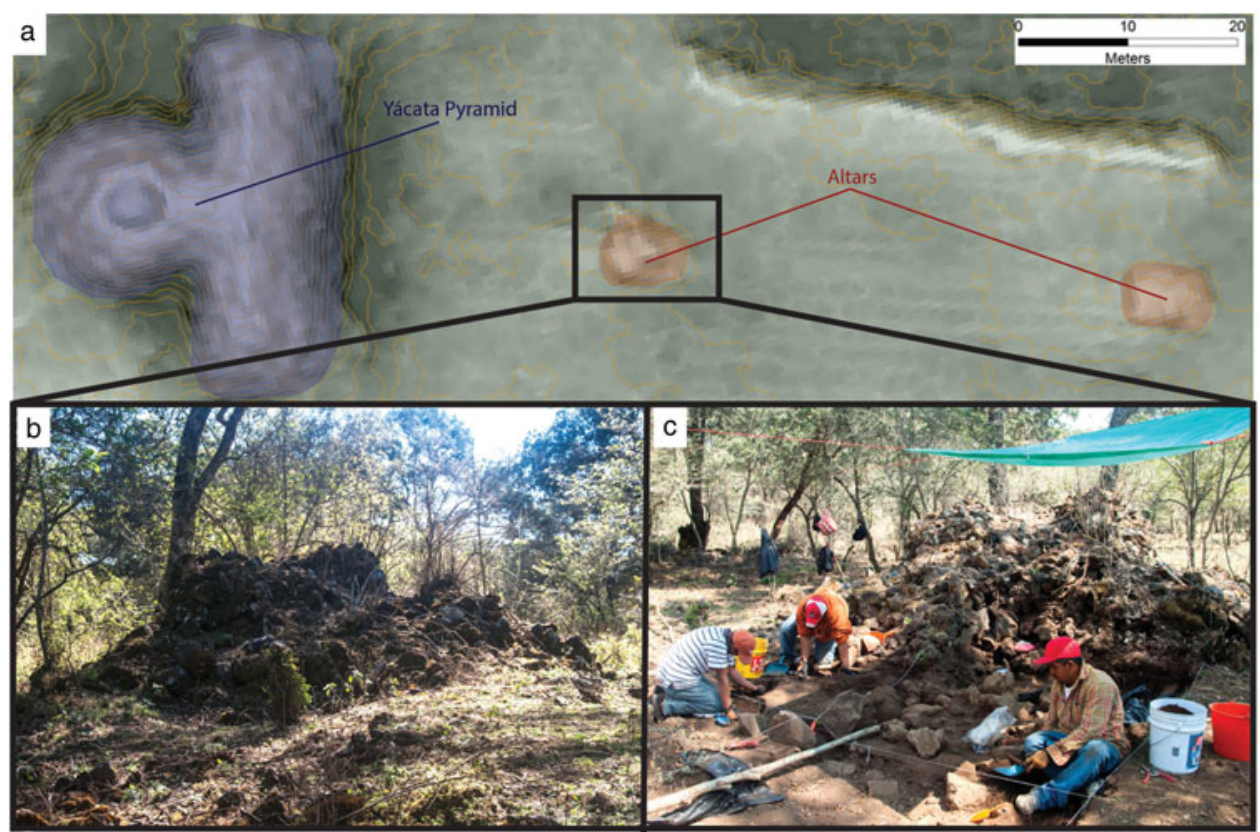

d

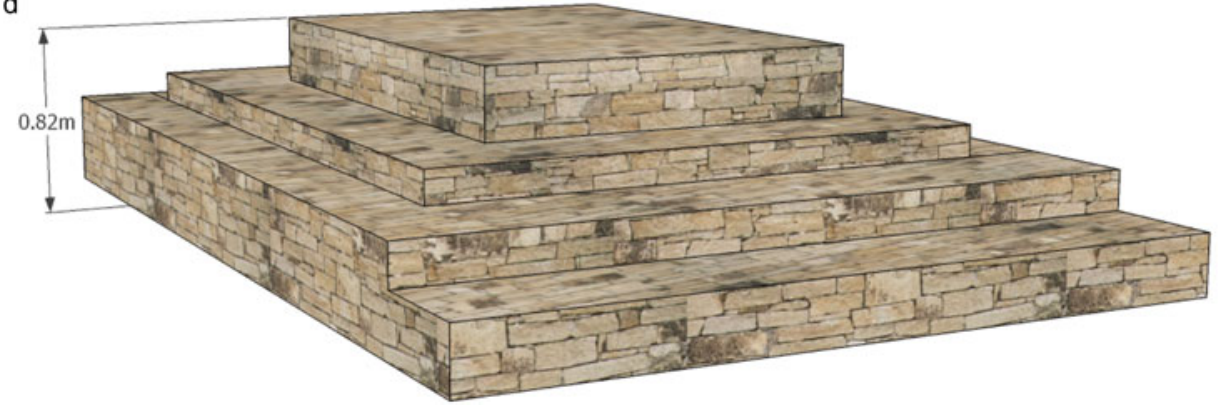

Figure 6. Altar examples. (a) Multiview hillshade with a $25 \mathrm{~cm}$ contour map of two large altars within a plaza adjacent to the yácata in Figure 4. All features are derived from $25 \mathrm{~cm}$ lidar data; (b) and (c) are photographs of an altar before and during excavation. (d) Reconstruction of an altar from a residential context.

indicate use of this feature in funerary activities during the Middle to Late Postclassic periods (1200-1530).

\section{Ground-Level Features}

Ground-level architectural features are characterized by square, linear, and circular forms that were the foundations for buildings made from perishable materials such as adobe, wattle and daub, or wooden/cane screens (Supplemental Figure 1b). Ground-level features are distinguished by the number of sides, their shape, and overall configuration.

Walls. The most basic ground-level feature is a wall, composed of a single course of stacked stone that is typically $50 \mathrm{~cm}$ wide (although thicker examples do exist) and range in height from $50 \mathrm{~cm}$ to $2 \mathrm{~m}$. Four subtypes of walls can be defined by their overall shape and total dimensions:

1. A simple wall is a feature that is less than $10 \mathrm{~m}$ long. Simple walls are likely the fragmented remains of buildings or socioeconomic markers such as boundaries. In practice, simple walls longer than $10 \mathrm{~m}$ are rare at Angamuco.

2. Like the L-shaped platform, the L-shaped wall consists of two linear sections forming a 90-degree angle. This wall subtype is thinner than the L-shaped platform but probably 
served the same function as open-sided houses or buildings (see the earlier discussion).

3. A passage or the space created with two parallel walls, typically separated by $50 \mathrm{~cm}$ to $1 \mathrm{~m}$. 4. A raised road (causeways and huatziris).

Square-Based Edificios. Ground-level structures with more than two walls are classified as either square-based or circular buildings (edificios). At Angamuco there are four formal types of square buildings based on the number of walls, their configuration, the overall shape of the building, and the presence or absence of a discrete entrance.

Type A has three walls and an open side. The fourth open side was presumably screened by a perishable wall and the entrance to the building. It is commonly small with an interior space that is roughly $1-2 \mathrm{~m}$ on a side.

Types B and C have four walls with an open area in one wall that forms an entrance. Type B has a rectilinear plan, whereas Type $\mathrm{C}$ is a square and is more common, especially in residential contexts. There are two variations in size and context that may be related to the building's function as a private (single family) or public (priest's quarters). Smaller versions of these types are 1-2 $\mathrm{m}$ on the shortest side, with a narrow entrance that averages $50 \mathrm{~cm}$ in width. There are larger examples of these features, although they are difficult to interpret because they occupy a wide range of settings and contexts. The size of these larger examples ranges from 4 to $10 \mathrm{~m}$. Buildings located near pyramids and large plazas may have served as priests' quarters as described in the RM. Elsewhere, larger versions of these features are embedded within plazas or elite complexes where they may have functioned as public buildings (Figure 7).

The fourth building type, the room, is a structure composed of four walls without a defined entrance. Rooms that occur singly are often associated with surface material suggesting a domestic occupation. Isolated rooms are rare in the Angamuco sample; more common are clusters of small rooms ( $1 \mathrm{~m}$ on a side) that are associated with large architectural complexes. These room complexes lack overall structural coherency and are difficult to interpret, although they are similar to features documented at Tzintzuntzan and
Tingambato (Piña Chan and Oi 1982; Rubín de la Borbolla 1941; Supplemental Figure 1d).

Circular. A second class of ground-level features is defined by circular foundations. Ahrens (2013) examined 296 circular features and identified two major prototypes based on diameter, morphology, and context. The first was likely a granary (cuexcomate), consisting of a circular stone foundation that varies in diameter from $<1-3.5 \mathrm{~m}($ mean $=2 \mathrm{~m})$, with a small $(25 \mathrm{~cm})$ entrance in one section of the foundation. Some granaries have semi-subterranean interiors with a shallow dished-out bottom, whereas other bases were made from small cobble pavements with an exterior apron. Similar to granaries in the Zacapu Basin (Forest 2014:223-234; Michelet and Forest 2012), the superstructure was probably composed of wattle and daube with an upper entrance and a thatch roof. Ahrens (2013) also found that granaries with variable diameters occur in public ritual, elite, and commoner contexts and that many are in highly visible locations, such as the edge of a plaza or adjacent to a road. The other likely circular ground-level feature, a possible sweat bath (temezcal), has a stone foundation that is greater than $3.5 \mathrm{~m}$ in diameter. Sweat baths are located on a small stepped platform that follows the outline of the overall feature and that includes a narrow step $(>30 \mathrm{~cm})$. They are described in the RM as where the king takes baths.

\section{Plazas}

In addition to ground-level and above-ground structures, there are features at Angamuco that represent intentional open or negative space (Supplemental Figure 1c; see Bush [2012] for details). The first such feature, the plaza, refers to an intentionally cleared, level, and open space (Inomata and Tsukamoto 2014). Open or ground-level plazas are cleared spaces that are usually large in size $\left(>10 \mathrm{~m}^{2}\right)$. They can have surrounding walls of stone and earth and may have adjacent buildings. Open plazas often form connections between neighboring building groups, landforms, and roadways.

In contrast, sunken plazas are rectangular or kidney-bean-shaped open spaces with one to three earthen or stone steps on all four sides. Located generally on higher elevations of the 

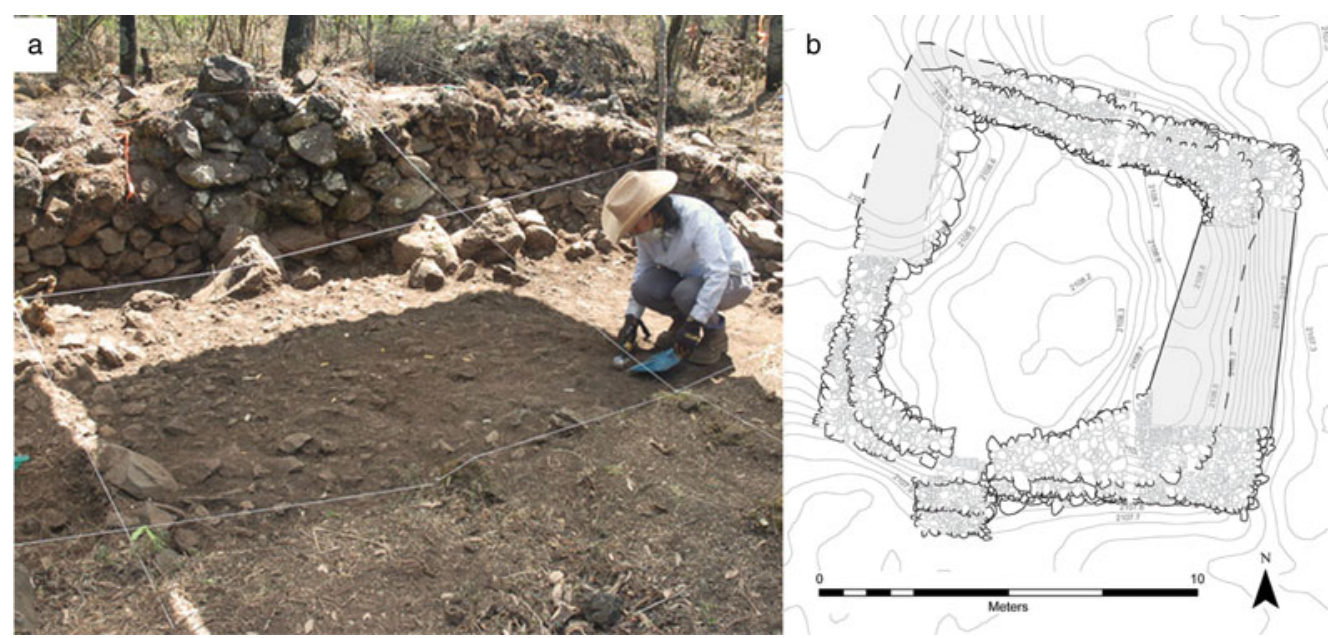

Figure 7. A large type $C$ room, in this instance a public structure excavated in 2013 (Casa 5128). (a) Casa 5128 looking north. (b) Plan map of this same structure (artwork by Karine Lefebvre and Christopher Fisher).

malpaís, sunken plazas vary in size from 250 to $1,000 \mathrm{~m}^{2}$ and may represent an extended household residential group, rather than public space (Bush 2012). Wider sections may have been built into the raised roadways, serving as bastions, ramps, or staircases, whereas others may have been used to contain water. A related feature that we classified is the patio, a small $\left(<10 \mathrm{~m}^{2}\right)$ ground-level plaza with paved or packed earth flanked by buildings. Access to these features was restricted and probably served a social group or family.

A final type of prepared open zone is the I-shaped ball court similar to those documented in the Zacapu Basin (Taladoire 1989; on Ihuatzio, see Cárdenas García 2004). It is likely that other forms are present at Angamuco as well, but the function of these more ambiguous features is harder to interpret. Figure 8 shows the largest of these features at Angamuco. A ballgame using sticks, called pelota tarasca, is still played in parts of Michoacán (Beals and Carrasco 1944; Corona Núñez 1957), and today some Purépecha communities participate in a game using a ball on fire.

\section{Landscape Features}

The final major architectural type at Angamuco is the landscape feature, which often appears between the features discussed earlier (Supplemental Figure 1c).
Terraces. We defined three major terrace subtypes. Agricultural terraces are $<3 \mathrm{~m}$ wide and are located on both steep and gentle slopes. At the Purépecha island treasury site of Apupáto, $1.5 \mathrm{~m}$ wide terraces were used for maguey cultivation (Pezzutti 2010). West (1948) reported the use of soil-retaining walls or terraces at the lower edges of hillside fields in Purépecha communities, which are similar to agricultural terraces elsewhere in highland Mesoamerica (Donkin 1979; Parsons and Parsons 1990; Rodríguez 2006). The second subtype is the habitation terrace, which is distinguished as $>3 \mathrm{~m}$ in width and is associated with domestic contexts like sunken plazas. These terraces often do not have architectural remains on the surface, although excavations indicate that they functioned as a platform for one or more residences. Finally, the architectural terrace is composed of stone benches or berms typically found in and around large buildings, pyramids, and other structures. These terraces probably supported architectural components or served as stairs leading to the top of features or both.

Units of Movement. Like other cities, at Angamuco there was great concern for space, access, and transport. As mentioned earlier, two additional wall types-passages (pasajes) and huatziri-functioned as access points within and between clusters of buildings, neighborhoods, and other sections of the city. A passage 


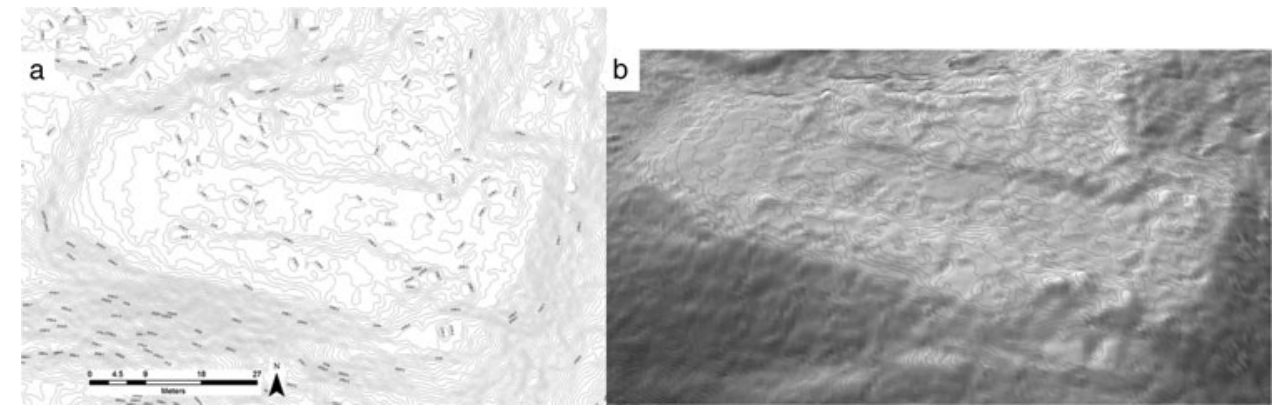

Figure 8. An I-shaped ball court. (a) Plan view of this feature with a $5 \mathrm{~cm}$ contour map. (b) Perspective view of this feature using the contour map and a hillshade. All features are derived from $25 \mathrm{~cm}$ resolution lidar data.

is the fundamental unit of movement in areas of complex architecture and is composed of an interior space formed by walls, platforms, or other adjacent architecture. Passages guided the circulation of people and materials inside complexes of architecture and defined entrances to distinct social places.

The final type of landscape modification are roads (Supplemental Figure 1E), which were visible during survey and in the lidar data. Roads at Angamuco are diverse in their construction style, shape, and extension; they are part of a complex network that links all areas of the site.

Most roads are typically less than $2 \mathrm{~m}$ wide and exhibit many of the features that are common among ancient transport networks in the Americas (e.g., Bolles and Folan 2001; Chase and Chase 2001; Cook and Carrión 1998; Trombold 1991; Snead et al. 2009). The road network of Angamuco is complex: the composition of each road segment, the network itself, and the associated architectural features include access ramps, stairs, curbs, and crossroads. For our initial approach, we established four classes based on length and accessibility to architectural features within the site. Tier 1 roads are generally more than $500 \mathrm{~m}$ long and are major thoroughfares connecting districts, traversing the malpaís topography, and highlighting formal entrances to the city. Tier 1 entrance roads are shorter than the other variations. Tier 2 roads are between $100 \mathrm{~m}$ to $500 \mathrm{~m}$ long and connected internal areas of the settlement, whereas tier 3 roads are less than $100 \mathrm{~m}$ long and connected clusters of buildings. Tier 4 roads are the same as passages described earlier, connecting individual buildings or domestic units.

\section{Discussion and Conclusions}

Although architectural typologies are fundamental for identifying architectural form and for potential planning purposes and serve as the basis for urban morphology, they are not commonly addressed in archaeology. In this article we presented an architectural typology for the city of Angamuco that represents an important first step toward understanding how ancient Purépecha people adapted to widespread dynamic environmental and sociopolitical conditions, such as those associated with empire formation in Postclassic western Mesoamerica. As a living document, this typology has undergone considerable evolution and modification since it was first introduced in 2007.

Angamuco comprises a dense urban landscape with thousands of architectural foundations that are preserved today. Based on a field-verified sample of more than 7,000 architectural features, the typology outlined here has allowed us to identify, document, and understand architectural patterning at Angamuco. The most common types of structures can be described as living spaces or housing features for both commoners and elites, including small platforms for houses and rectangular and circular walled rooms. The second most common features are structures for public or ritual activities, such as pyramids, plazas, and a ball court. Finally, a small part of our sample are structures associated with agriculture activities such as patios or terraces; however, we expect that additional terraces will be visible in future mapping projects.

The diverse range of structures at Angamuco suggests a large, active, and organized population 
embedded within an extensive human modified landscape. Based on our architectural sample and chronological information from excavations, the Angamuco urban plan and demographics likely changed throughout the Postclassic period. During the Early to Middle Postclassic periods, residents lived throughout the malpaís in distinctive neighborhoods with plazas and gardens. During the Late Postclassic period, when the Purépecha Empire exerted control in the LPB and throughout western Mexico, some areas of the site were abandoned. These imperial period settlements are represented by the yácatas and monumental architecture discussed earlier. Other former residents may have left Angamuco for imperial cities such as Tzintzuntzan and Ihuatzio. Importantly, the process of population growth during the Early to Middle Postclassic and then abandonment in the Late Postclassic also occurred at the malpaís sites in the Zacapu Basin. At Prieto, scholars argue that the houses and neighborhoods were ritually closed as residents moved to the more cosmopolitan Purépecha sites in the LPB (Migeon 2003). It is possible that a similar process occurred at Angamuco.

Western Mexico is a Mesoamerican core area, and an understanding of Purépecha urbanism is fundamental to broader interpretations of Mesoamerican city planning. This article represents the first architectural typology for the LPB, the heartland of the Purépecha Empire. In the future, Angamuco architecture may be compared to other architectural studies in western Mexico (e.g., Forest 2008, 2014; Ohnersorgen and Varien 1996), which will help us better understand the urban pattern in this relatively understudied part of Mesoamerica. In particular, the Angamuco data can be compared to work in the Zacapu Basin, where residents lived in small $\left(\sim 1 \mathrm{~km}^{2}\right)$ cities on malpaís landforms throughout much of the Postclassic period. Some of the Angamuco architecture is similar to the Zacapu types, such as the circular granaries, ball courts, rectangular-based pyramids, and domestic spaces. In contrast, the Zacapu sites do not have semi-circular yácatas, and few imperialstyle artifacts have been recovered (Jadot 2016). This supports the interpretation discussed earlier that these sites were abandoned around the time of empire formation. Other questions relate to how the Angamuco architecture compares with features elsewhere in the pre-imperial territories, such as in the Tierra Caliente and the Sayula and Cuitzeo Basins. With the exception of the Zacapu research, very little work has been done on domestic spaces in Purépecha archaeology, and Angamuco provides an excellent context for evaluating commoner lifeways.

There is a renewed emphasis on comparative approaches to prehistory as archaeologists seek ways to better address cross-cultural problems that have meaning to stakeholders and policy makers (M. E. Smith 2011). The increasing use of lidar, computer modeling, and other techniques that are ushering in new preservation methods is facilitating such approaches (Fernandez-Diaz et al. 2018; Llobera 2011). To achieve comparative goals and to analyze big data, archaeologists must new find ways to categorize, quantify, and analyze large and varied types of qualitative and quantitative data. Our field sample is one way to apply computational analysis to a large site using lidar data. Using such datasets, we can understand more about the urban layout of sites that are not always well preserved. Although modern construction and erosion will always be a problem for archaeologists, a bird's-eye urban map can help. We are just scratching the surface of Angamuco research, and this typology forms the foundation for ongoing and future work at the site.

Acknowledgments. This analysis was supported by grants to Chris Fisher from the National Science Foundation (BCS 0818662, BCS 1220016), the National Geographic Society, the NASA Space Archaeology Program, and Colorado State University. We thank the Fontezuelas community, the Tzintzuntzan municipal government, the Tzintzuntzan Community Heritage Council, INAH-Michoacán, and the LORE-LPB field crews between 2009 and 2014 for their help. We appreciate the comments of three anonymous reviewers, which have improved this article.

Data Availability Statement. All data are available upon request from the senior author.

Supplemental Material. To view supplementary material for this article, please visit http://doi.org/10.1017/laq.2019.50

Supplemental Figure 1. Decision tree for the Angamuco architectural typology. 


\section{References Cited}

Acosta, Jorge R.

1939 Exploraciones arqueológicas realizadas en el estado de Michoacán durante los años de 1937 y 1938. Revista Mexicana de Estudios Antropológicos 3(2):85-98.

Adams, William Y.

1988 Archaeological Classification-Theory versus Practice. Antiquity 62:40-56.

Ahrens, Corrie

2013 Cuexcomate or Temezcal? Deciphering the Circular Architectural Features at Angamuco, Michoacan, Mexico. Master's thesis, Department of Anthropology, Colorado State University, Fort Collins.

Alcalá, Jerónimo de

2000 Relación de Michoacán. Fondo de Cultural Económica, Mexico City.

Allison, Penelope

2013 The Archaeology of Household Activities. Routledge, London.

Anschuetz, Kurt F., Richard H. Wilshusen, and Cherie L. Scheick

2001 An Archaeology of Landscapes: Perspectives and Directions. Journal of Archaeological Research 9:157-211

Arnauld, Charlotte, and Brigitte Faugère-Kalfon

1998 Evolución de la ocupación humana en el CentroNorte de Michoacán (Proyecto Michoacán, CEMCA) y la emergencia del Estado Tarasco. In Génesis, culturas, y espacios en Michoacán, edited by Véronique Darras, pp. 13-34. CEMCA, Mexico City.

Ashmore, Wendy

1981 Some Issues of Method and Theory in Lowland Maya Settlement Archaeology. In Lowland Maya Settlement Patterns, edited by Wendy Ashmore, pp. 37-69. University of New Mexico Press, Albuquerque.

2002 "Decisions and Dispositions": Socializing Spatial Archaeology. American Anthropologist 104:11721183.

2015 What Were Ancient Maya Landscapes Really Like? Journal of Anthropological Research 71:205-326.

Barrett, John C.

1994 Fragments from Antiquity: An Archaeology of Social Life in Britain, 2900-1200 BC. Blackwell, Oxford.

Barthelemy, Ricardo, and Jean Meyer

1987 La casa en el bosque: Las "trojes" de Michoacán. El Colegio de Michoacán, Zamora, Mexico.

Batty, Michael

2008 The Size, Scale, and Shape of Cities. Science 319 (5864):769-771.

Beals, Ralph L., and Pedro Carrasco

1944 Games of the Mountain Tarascans. American Anthropologist 46:516-522.

Beals, Ralph Leon, Pedro Carrasco Pizana, and Thomas McCorkle

1944 Houses and House Use of the Sierra Tarascans. U.S. Government Printing Office, Washington, DC.

Beaumont, Pablo de la Purísima Concepción

1932 Crónica de Michoacán. Vol. 2. Talleres Gráficos de la Nación, Mexico City.

Bolles, David, and William J. Folan

2001 An Analysis of Roads Listed in Colonial Dictionaries and their Relevance to Pre-Hispanic Linear Features in the Yucatan Peninsula. Ancient Mesoamerica 12:299-314.
Bourdieu, Pierre

1977 Outline of a Theory of Practice. Cambridge University Press, Cambridge.

Bradley, Richard

2000 An Archaeology of Natural Places. Psychology Press, Washington, DC.

Bush, Jason

2012 Architectural Patterning in the Purépecha Heartland: An Intrasite Settlement Study at the Urban Center of Sacapu Angamuco, Michoacán, México. Master's thesis, Department of Anthropology, Colorado State University, Fort Collins.

Carballo, David M.

2011 Advances in the Household Archaeology of Highland Mesoamerica. Journal of Archaeological Research 19:133-189.

Carballo, David M., and Brent Fortenberry

2015 Bridging Prehistory and History in the Archaeology of Cities. Journal of Field Archaeology 40:542-559.

Cárdenas García, Efraín

1991 Proyecto Ihuatzio. INAH, Mexico City.

1992 Informe de las exploraciones realizadas en Ihuatzio, Michoacán, 1991. INAH, Mexico City.

1993 Informe: Proyecto Ihuatzio, Michoacán. Segunda temporada. INAH, Mexico City.

1999 El Bajío en el clásico: Análisis regional y organización política. El Colegio de Michoacán, Zamora, Mexico.

2004 Jiuatsio, "la casa del coyote." In Tradiciones arqueológicas, edited by Efraín Cárdenas García, pp. 195-215. El Colegio de Michoacán, Zamora, Mexico.

Castro-Leal Espino, Marcia

1986 Tzintzuntzan: Capital de los tarascos. Gobierno del Estado de Michoacán, Morelia, Mexico.

Chase, Arlen F., and Diane Z. Chase

2001 Ancient Maya Causeways and Site Organization at Caracol, Belize. Ancient Mesoamerica 2:273-281.

Cohen, Anna S.

2016 Creating an Empire: Local Political Change at Angamuco, Michoacan, Mexico. PhD dissertation, Department of Anthropology, University of Washington, Seattle.

Cook, Angel García, and Beatriz Leonor Merino Carrión

1998 Cantona: Urbe Prehispánica en el Altiplano Central de Mexico. Latin American Antiquity 9:191-216.

Corona Núñez, José

1957 Mitología tarasca. Fondo de Cultura Económica, Mexico City.

Darras, Veronique, and Brigitte Faugère

2005 Cronología de la cultura Chupícuaro: Estudio del sitio La Tronera, Puruagüita, Guanajuato. In El Antiguo occidente de México: Nuevas perspectivas sobre el pasado prehispánico, edited by Eduardo Williams, Phil C. Weigand, Lorenza López Mestas, and David C. Grove, pp. 255281. El Colegio de Michoacán, Zamora, Mexico.

Denevan, William M.

1990 Prehistoric Roads and Causeways of Lowland Tropical America. In Ancient Road Networks and Settlement Hierarchies in the New World, edited by Charles Trombold, pp. 231-242. Cambridge University Press, Cambridge.

Donkin, Robin Arthur

1979 Agricultural Terracing in the Aboriginal New World. Viking Fund Publications in Anthropology. University of Arizona Press, Tucson.

Dunnell, Robert C.

1986 Methodological Issues in Americanist Artifact Classification. Advances in Archaeological Method and Theory 9:149-207. 
Du Solier, Wilfrido

1936 Informe sobre las zonas arqueológicas de Copalilla, Ihuatzio, Zacapu y La Angostura, Michoacán. INAH, Mexico City.

Faugère-Kalfon, Brigitte

1996 Entre Zacapu y Río Lerma: Culturas en una zona fronteriza. CEMCA, Mexico City.

Fernandez-Diaz, Juan Carlos, Anna S. Cohen, Alicia González, and Christopher T. Fisher

2018 Shifting Perspectives and Ethical Concerns in the Era of Remote Sensing Technologies. SAA Archaeological Record 18(2):8-15.

Fisher, Christopher T., Jason Bush, Anna S. Cohen, and Florencia Pezzutti

2011 Proyecto Informe Técnico Parcial, Temporada 2010. INAH, Mexico City.

Fisher, Christopher T., Anna S. Cohen, Juan Carlos Fernandez Diaz, and Stephen J. Leisz

2017 The Application of Airborne Mapping LiDAR for the Documentation of Ancient Cities and Regions. Quaternary International 448:129-138.

Fisher, Christopher T., Anna S. Cohen, Karine Lefebvre, Florencia Pezzutti, Rodrigo Solinis-Casparius, and Kyle Urquhart,

2013 Proyecto Informe Técnico Parcial, Temporada 2013. INAH, Mexico City.

Fisher, Christopher T., Anna S. Cohen, Karine Lefebvre, Florencia Pezzutti, Rodrigo Solinis-Casparius, and Kyle Urquhart,

2016 Proyecto Informe Técnico Parcial, Temporada 2013. INAH, D.F. Mexico.

Fisher, Christopher T., Anna S. Cohen, Florencia Pezzutti, and Rodrigo Solinis-Casparius

2012 Proyecto Informe Técnico Parcial, Temporada 2011. INAH, Mexico City.

Fisher, Christopher, and Stephen Leisz

2013 New Perspectives on Purepecha Urbansim through the Use of LiDAR at the Site of Angamuco, Mexico. In Mapping Archaeological Landscapes from Space, edited by Douglas C. Comer and Michael J. Harrower, pp. 199-213. Springer, New York.

Fisher, Christopher T., Stephen Leisz, and Gary Outlaw

2011 Lidar-A Valuable Tool Uncovers an Ancient City in Mexico. Photogrammetric Engineering and Remote Sensing 77:962-967.

Forest, Marion

2008 Identification et utilisation des espaces du site de El Malpaís Prieto, Michoacán, Mexique. Master's thesis, Department of Anthropology, Université Paris 1-PanthéonSorbonne, Paris.

2014 L'organisation sociospatiale des sites urbains du Malpais de Zacapu, Michoacan, Mexique [1250-1450 après J.-C.). PhD dissertation, Department of Anthropology, Université Paris 1-Panthéon-Sorbonne, Paris.

2017 La transition urbaine du Centre-Ouest mexicaine au $\mathrm{XIII}^{\mathrm{e}}$ siècle: Entre fondations et refondations. In $(R e)$ Fonder: Les modalités du (re)commencement dans le temps et dans l'esapce, edited by Philippe GervaisLambony, Frédéric Hurlet, and Isabelle Rivoal, pp. 157-168. Éditions de Boccard, Paris.

Gali, Ramón

1946 Arqueología de Tzintzuntzan. Anales del Museo Michoacano (Morelia) 2(4):50-62.

Giddens, Anthony

1984 The Constitution of Society: Outline of the Theory of Structuration. University of California, Berkeley.
Goggin, John M.

1943 An Archaeological Survey of the Rio Tepalcatepec Basin, Michoacán, Mexico. American Antiquity 9:44-58.

Ingold, Tim

1993 The Temporality of the Landscape. World Archaeology 25:152-174.

Inomata, Takeshi, and Kenichiro Tsukamoto

2014 Mesoamerican Plazas: Arenas of Community and Power. University of Arizona Press, Tucson.

Jadot, Elsa

2016 Productions céramiques et mobilités dans la région tarasque de Zacapu (Michoacan, Mexique): Continuités et ruptures techniques entre 850 et 1450 apr. J.-C. PhD dissertation, Department of Anthropology, Université de Paris 1-Panthéon Sorbonne, Paris.

Johnson, Matthew H.

2012 Phenomenological Approaches in Landscape Archaeology. Annual Review of Anthropology 41:269-284.

Joyce, Arthur A., and Michelle Goman

2012 Bridging the Theoretical Divide in Holocene Landscape Studies: Social and Ecological Approaches to Ancient Oaxacan Landscapes. Quaternary Science Reviews 55:1-22.

León, Nicolás

1886 Studies on the Archaeology of Michoacan (México). Unpublished manuscript. https://books.google.com/books/ about/Studies_on_the_Archaeology_of_Michoacan.html? id=OTIbygAACAAJ.

Lippard, Lucy R.

1997 The Lure of the Local: Senses of Place in a Multicentered Society. New Press, New York.

Llobera, Marcos

2011 Archaeological Visualization: Towards an Archaeological Information Science (AISc). Journal of Archaeological Method and Theory 18:193-223.

Lumholtz, Carl

1987 Unknown Mexico: Explorations in the Sierra Madre and Other Regions, 1890-1898. Dover, New York.

Marcus, Joyce, and Jeremy A Sabloff (editors)

2008 The Ancient City: New Perspectives on Urbanism in the Old and New World. SAR Press, Santa Fe, New Mexico.

Marquina, Ignacio

1929 Informe acerca del estudio de las yácatas al norte del pueblo de Ihuatzio, lago de Pátzcuaro, Michoacán. INAH, Mexico City.

Mastache, Alba Guadalupe, Robert Cobean, Angel Garcia-Cook, and Kenneth G. Hirth (editors)

2008 El urbanismo en Mesoamérica/Urbanism in Mesoamerica. Vol. 2. INAH, Mexico City; Pennsylvania State University, University Park.

Michelet, Dominque

2008 Vivir Diferentement. Los sitios de la fase Milpillas (1250-1450 d.C.). In El urbanismo en Mesoamérical Urbanism in Mesoamerica, Vol. 2, edited by Alba Guadalupe Mastache, Robert Cobean, Angel GarciaCook, and Kenneth G. Hirth, pp. 593-621. INAH, Mexico City; Pennsylvania State University, University Park. Michelet, Dominique, and Marion Forest

2012 Almacenar en El Malpaís de Zacapu, Centro-Norte de Michoacan (1250-1450 d. C.). In Almacenamiento prehispánico del Norte de México al Altiplano Central, edited by Séverine Bortot, Dominique Michelet, and Véronique Darras, pp. 121-130. CEMCA, Mexico City. Migeon, Gérald

2003 Abandonos programados, rituales de «matanza» o 
de terminación, reocupaciones: Los casos del Cerro Barajas, Guanajuato y de Milpillas en el Malpaís de Zacapu, Michoacán. Trace 43:3-9.

Millon, René

1973 The Teotihuacán Map. University of Texas Press, Austin.

Ohnersorgen, Michael, and Mark D. Varien

1996 Formal Architecture and Settlement Organization in Ancient West Mexico. Ancient Mesoamerica 7:103-120.

Oliveira, Vítor

2016 Urban Morphology: An Introduction to the Study of the Physical Form of Cities. Springer, New York.

Oliveira, Vitor, Claudia Monteiro, and Jenni Partanen

2015 A Comparative Study of Urban Form. Urban Morphology 19:73-92.

Ortman, Scott G., Andrew H. F. Cabaniss, Jennie O. Sturm, and Luís M. A. Bettencourt

2014 The Pre-History of Urban Scaling. PLoS ONE 9(2): e87902.

Parsons, Jeffrey R., and Mary Hrones Parsons

1990 Maguey Utilization in Highland Central Mexico: An Archaeological Ethnography. Museum of Anthropology, University of Michigan, Ann Arbor.

Pepper, George $\mathrm{H}$

1916 Yacatas of the Tierra Caliente, Michoacan, Mexico. J. W. Bryan Press, Washington, DC.

Pereira, Grégory, Marion Forest, Dominique Michelet, Elsa Jadot, Luis Barba, Brigitte Faugère, Michelle Elliott, and Aurélie Manin

2012 Proyecto Uacúsecha: Informe técnico sobre los trabajos de campo llevados a cabo en Malpaís Prieto y otros asentamientos de la region de Zacapu, Michoacán. Temporada 4 (2011-2012). INAH, Mexico City.

Pezzutti, Florencia

2010 The Steps of Kings: Terraced Landscapes in the Lake Pátzcuaro Basin, Michoacán, México. Master's thesis, Department of Anthropology, Colorado State University, Fort Collins.

Piña Chan, and Kuniaki Oi

1982 Exploraciones arqueologicas en Tingambato, Michoacan. INAH, Mexico City.

Pollard, Helen Perlstein

1993 Tariacuri's Legacy: The Prehispanic Tarascan State. University of Oklahoma Press, Norman.

2003 Central Places and Cities in the Core of the Tarascan State. In Urbanism in Mesoamerica, Vol. 1, edited by William T. Sanders, Alba Guadalupe Mastache, and Robert H. Cobean, pp. 345-390. INAH, Mexico City; Pennsylvania State University, University Park.

Pollock, H. E. D

1936 Round Structures of Aboriginal Middle America. Carnegie Institution, Washington, DC.

Pomédio, Chloé, Grégory Pereira, and Eugenia FernándezVillanueva (editors)

2013 Tradiciones cerámicas del epiclásico en el Bajío y regiones aledañas: Cronología e interacción. British Archaeological Reports, Oxford.

Preucel, Robert W.

2008 Archaeological Semiotics. Wiley, New York.

Puaux, Olivier

1989 Les Pratiques funéraires tarasques (état du Michoacan, Mexique): Approches éthnohistorique et archéologique. Phd dissertation, Department of Anthropology, University of Paris, Paris.

Robles, Concepción Cruz, José Rodolfo Cid Beziez, and Salvador Pulido Méndez
2014 Lagunillas, un sitio uacúsecha en la periferia de la Meseta Tarasca. Arqueología 47:67-89.

Rodríguez, Verónica Pérez

2006 States and Households: The Social Organization of Terrace Agriculture in Postclassic Mixteca Alta, Oaxaca, Mexico. Latin American Antiquity 17:3-22.

Roskamp, Hans

1997 Pablo Beaumont and the Codex of Tzintzuntzan: A Pictorial Document from Michoacán, West México. In Códices, caciques y comunidades, edited by Maarten Jansen and Luis Reyes García, pp. 193-245. Ridderkerk, AHILA, Cuadernos de Historia Latinoamericana, Amsterdam.

Rubín de la Borbolla, Daniel

1939 Antropología Tzintzuntzan-Ihuatzio. Revista Mexicana de Estudios Antropológicos 3:99-121.

1941 Exploraciones arqueológicas en Michoacán: Tzintzuntzan Temporada III. Revista Mexicana de Estudios Anthropológicas 5:5-20.

1944 Orfebrería tarasca. Cuadernos Americanos 15 (3):127-138.

Sanders, William, Alba Guadalupe Mastache, and Robert Cobean (editors)

2003 El urbanismo en Mesoamérica/Urbanism in Mesoamerica, Vol. 1. INAH, Mexico City; Pennsylvania State University, University Park.

Scheer, Brenda, C.

2010 The Evolution of Urban Form: Typology for Planners and Architects. Routledge, New York.

Smith, Michael E.

2007 Form and Meaning in the Earliest Cities: A New Approach to Ancient Urban Planning. Journal of Planning History 6:3-47.

2008 Aztec City-State Capitals. University Press of Florida, Gainesville.

2011 Empirical Urban Theory for Archaeologists. Journal of Archaeological Method and Theory 18:167-192.

Smith, Monica L.

2003 The Social Construction of Ancient Cities. Smithsonian Institution, Washington, DC.

2014 The Archaeology of Urban Landscapes. Annual Review of Anthropology 43:307-323.

Snead, James E., Clark L. Erickson, and J. Andrew Darling (editors)

2009 Landscapes of Movement: Trails, Paths, and Roads in Anthropological Perspective. University of Pennsylvania Press, Philadelphia.

Spaulding, Albert C.

1953 Statistical Techniques for the Discovery of Artifact Types. American Antiquity 18:305-313.

Stanley, Benjamin W., Timothy J. Dennehy, Michael E. Smith, Barbara L. Stark, Abigail M. York, George L. Cowgill, Juliana Novic, and Jerald Ek

2016 Service Access in Premodern Cities: An Exploratory Comparison of Spatial Equity. Journal of Urban History 42:121-144.

Steadman, Sharon R.

2016 Archaeology of Domestic Architecture and the Human Use of Space. Routledge, London.

Taladoire, Eric

1989 Las canchas de juego de pelota de Michoacán (CEMCA: Proyecto Michoacán). Trace 16:88-99.

Tilley, Christopher

1994 A Phenomenology of Landscape: Places, Paths, and Monuments. Berg, Oxford. 
Trombold, Charles D.

1991 An Introduction to the Study of Ancient New World Road Networks. In Ancient Road Networks and Settlement Hierarchies in the New World, edited by Charles Trombold, pp. 1-9. Cambridge University Press, Cambridge.

Urquhart, Kyle Ryan

2015 The Ireta: A Model of Political and Spatial Organization of P'urépecha Cities. Master's thesis, Department of Anthropology, Colorado State University, Fort Collins.

Villafanez, Emilio Alejandro

2011 Entre la geografía y la arqueología: El espacio como objeto y representación. Revista de Geografía Norte Grande 50:135-150.
Walker, John H.

2012 Recent Landscape Archaeology in South America. Journal of Archaeological Research 20:309-355.

West, Robert C.

1948 Cultural Geography of the Modern Tarascan Area. U.S. Government Printing Office, Washington, DC.

York, Abigail M., Michael E. Smith, Benjamin W. Stanley, Barbara L. Stark, Juliana Novic, Sharon L. Harlan, George L. Cowgill, and Christopher G. Boone

2011 Ethnic and Class Clustering through the Ages: A Transdisciplinary Approach to Urban Neighbourhood Social Patterns. Urban Studies 48:2399-2415.

Submitted October 24, 2018; Revised April 14, 2019; Accepted June 11, 2019 